\title{
Applying Sustainable Development in Architecture, Planning and Infra-Structure of Abha to be the First Eco-City in the Middle East
}

\author{
Wael A. Aboneama ${ }^{1}$
}

\begin{abstract}
Sustainability improvement in Saudi Arabia and the whole Middle East is focused on only buildings and small projects. However, the history of architecture in the Middle East starting from 7th century to the end of 19 th century was the real beginning of sustainable design and development. Nowadays, there is no wide planning to take a step forward towards sustainable city. Abha in Saudi Arabia could be one of the best inceptions as a sustainable city. Its climate puts Abha in the first places to be selected for applying sustainable development. Abha is the biggest city in Asir territory and the capital of tourism in Saudi Arabia. It is located 2,200 meters above the sea level with a prolific soil on the mountains of south-western Saudi Arabia (Hoiberg D. H., 2010). All over the year, the temperature moves from its lowest level around $7 \mathrm{C}^{\circ}$ to its maximum of $28 \mathrm{C}^{\circ}$ (Weather spark, n.d.). The average rainfall is $278 \mathrm{~mm}$, which means that it is enough for human use and irrigation. This paper is focusing on studying the actual situation of Abha's development and apply sustainable criteria on its architecture, planning and infra-structure to move it inside the territory of eco-cities.
\end{abstract}

Keywords: Sustainable development, Abha, Architecture, Infra-structure, sustainable city

\section{Introduction}

First of all we should be more familiar and closer to the definition of sustainable cities and the difference between them against normal cities. Many cities such as Copenhagen, Amsterdam, Stockholm, Vancouver, London and more achieved the level of eco-cities. Those cities are enjoying living in high-quality of healthy life, less energy and water consumption, better land-use, and economic returns (Rigester, 2008). Most of Middle East cities are suffering from several environmental, economic, social, and landuse problems. The sample of Masdar city in UAE fig (1) as a sustainable city could be adequate for new urban development, but it is not convenient for an existing old cities which is the case of most of Middle East cities.

Fig. (1) Masdar city, UAE (Willmott, 2014)

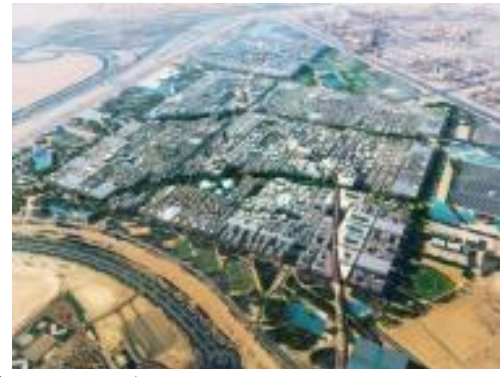

$\mid{ }^{1}$ Dr., Associate professor at King Khalid University, Faculty of Engineering, Abha, Saudi Arabia \& Helwan University, Faculty of Fine Arts, Cairo, Egypt 
Abha is the biggest city in Asir territory Fig. (2). It has a big potential to be a sustainable city. Its weather, rainfall average and surrounding environment are motivations to select Abha as one of the best cities for living in the Middle East. It was selected as the capital of Arab tourism in 2017 (Abdallah, 2017). The summer is long, warm, arid, and partly cloudy and the winter is short, cool, dry, and mostly clear.

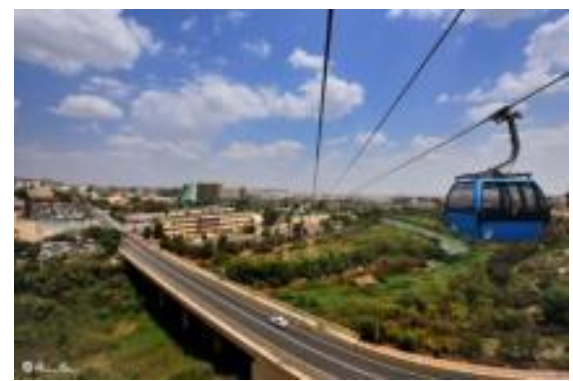

Fig. (2) Abha city, Saudi Arabia (Abir, 2015)

On the other hand, the Middle East region is thirsty for sustainable development in particular the Arabian Peninsula. The common weather is very hot and the use of renewable energy is not compatible with the available solar and wind powers. In addition, potable water resources are scarce. Table (1) describes that the fossil fuels are the most important source of energy in Saudi Arabia. The rest of the countries in Arabian Peninsula are not much better. The most important measure in the energy balance of Saudi Arabia is the total consumption of 292.80 billion kWh of electric energy per year. Per capita this is an average of $9,072 \mathrm{kWh}$. The electricity consumption in Saudi Arabia increased from 219.66 terawatt in 2011 to 287.44 terawatt in 2016 which means $30 \%$ in only five years.

Table (1) describes the energy sources in Saudi Arabia compared with Europe in 2014. (saudiarabia/energy-consumption, n.d.)

\begin{tabular}{|c|c|c|c|c|c|}
\hline Energy source & $\begin{array}{r}\text { Total } \\
\text { in Saudi Arabia } \\
\end{array}$ & $\begin{array}{r}\text { percentage } \\
\text { in Saudi Arabia } \\
\end{array}$ & $\begin{array}{l}\text { percentays } \\
\text { in Europe }\end{array}$ & $\begin{array}{r}\text { per capita } \\
\text { in Saudi Arabia } \\
\end{array}$ & $\begin{array}{l}\text { per capita } \\
\text { in Europe }\end{array}$ \\
\hline Fossil fues: & $604.27 \mathrm{ban} \mathrm{kWh}$ & $99,9 \%$ & 48,946 & $18,722.24 \mathrm{kWh}$ & $7,994.86 \mathrm{kWh}$ \\
\hline Nuslear poner & $0.00 \mathrm{kWh}$ & $0.0 \%$ & $7,2 \%$ & $0.00 \mathrm{kWh}$ & $1,105,07 \mathrm{kwh}$ \\
\hline Wrater power & $0.00 \mathrm{kWh}$ & $0,0 \%$ & $29,4 \%$ & $0.00 \mathrm{kWh}$ & $3,829.5 \mathrm{twh}$ \\
\hline Renenable energy & $604.88 \mathrm{~m}$ kWh & $0,1 \%$ & $16,2 \%$ & $18.76 \mathrm{kWh}$ & $2,655.34 \mathrm{kWh}$ \\
\hline Other energy sources & $0.00 \mathrm{kwh}$ & $0,0 \%$ & $4,3 \%$ & $0.00 \mathrm{kWh}$ & $696.17 \mathrm{kWh}$ \\
\hline Total productise capacty & $604.88 \mathrm{ba} \mathrm{kWh}$ & $100,0 \%$ & $100,0 \%$ & $18,740.98 \mathrm{kWh}$ & $16,362.15 \mathrm{kWh}$ \\
\hline
\end{tabular}

On 25th of April 2016, a future vision 2030 for Saudi Arabia was announced for the upcoming fifteen years. It is a plan to reduce Saudi Arabia's dependence on oil, diversify its economy, and develop public service sectors such as health, education, infrastructure, recreation and tourism (Wikipedia, 2016). Of all the above, Abha city as a case study inside Saudi Arabia is a perfect choice to start with a new target of transforming Middle East cities to eco-cities. Finally, what should we do to develop any city to be an eco-city or sustainable city? 


\section{Literature Review}

\subsection{Sustainable Cities (Eco-Cities)}

Sustainable city, urban sustainability and eco-city are several terminologies of considering the three principles which are ecology, people, and economy without any negative impact of future generation's natural resources. These cities are inhabited by people whom are dedicated towards minimization of required inputs of energy, water, food, waste, output of heat, air pollution - CO2, methane, and water pollution (en.wikipedia.org, 2008). 1987 was the first time for the term of "eco-city" written by Richard Register in his book "Eco-city Berkeley: Building Cities for a Healthy Future". Eco-city defines as the design and planning on the synergy and interdependence of ecological and economic sustainability, and their fundamental ability to reinforce each other in the urban context (Hiroaki Suzuki, 2010)

Fig. (3) Copenhagen, Denmark (vacationidea, 2016)

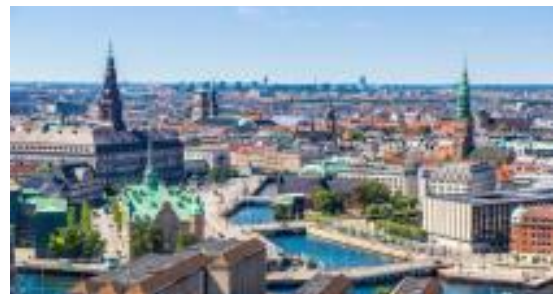

\subsection{Eco-City Models in the world}

The Global Green Economy Index (GGEI) $4^{\text {th }}$ edition with a deep study of more than 60 countries and 70 cities which passed through a long path of environmentally friendly economies with actual performance. Copenhagen, Amsterdam, Stockholm, Vancouver, London, Berlin, New York, Singapore, Helsinki, and Oslo are selected in order as the top ten eco-cities in the world. (Pantsios, 2014).

On the other hand, Xuzhou is another sample of the three eco-cities in China fig. (4). The transforming of this city was based on sustainable development of health, social, solid and waste water, traffic and transportation, energy, urban function, economic development, primary, secondary and tertiary industry. One obstacle faced this city, was that the frameworks have not been developed bottom-up in a local participation process. Xuzhou clarifies the importance of cooperation between the different city departments responsible for energy, water, and transportation (Liu, Wennersten, Luo, Jiang, \& Dong, 2016).

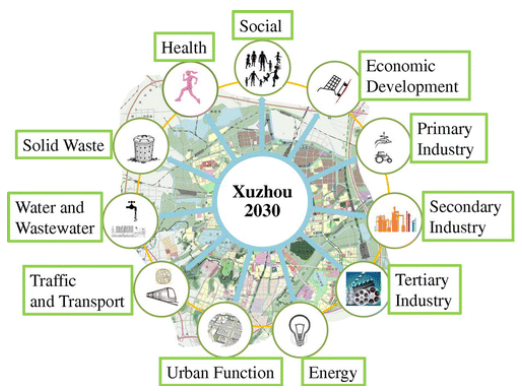

Fig. (4) Xuzhou eco-city 2030, China (Liu, Wennersten, Luo, Jiang, \& Dong, 2016) 


\subsection{The World Bank and Ecological Cities}

Ecological Cities are motivated by the World Bank, as an integral part of its Urban and Local Government Strategy, to help cities in developing countries achieve greater ecological and economic sustainability (Hiroaki Suzuki, 2010). The World Bank's interest of eco-cities is a great advantage for any country to start working hard to transform its cities to be sustainable cities.

\subsection{The Transportation in Abha}

The main mean of transportation in Abha city is the private cars. Unfortunately, there is no public transportation in Abha such as buses, tram, or trolley-bus. However, the planning of the city and the neighbouring city Khamis Mushait based on high-way and ring roads connecting most of the attraction points. Fig (5) \& (6). This leads to two outcomes. First one, fuel consumption and carbon emissions now at the worst level compared to the population. Secondly, developing a sustainable public transportation plan using all possible means of sustainable transportation is much easier than any other city based on its planning and kingdom vision 2030.

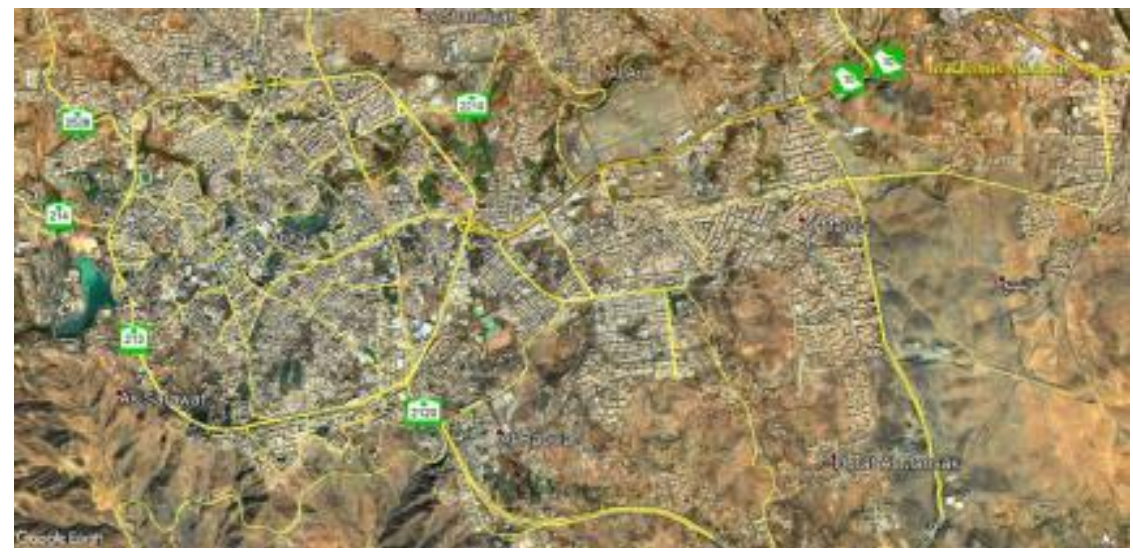

Fig. (5) Illustrates Abha city roads \& streets. (By researcher using Google Earth)

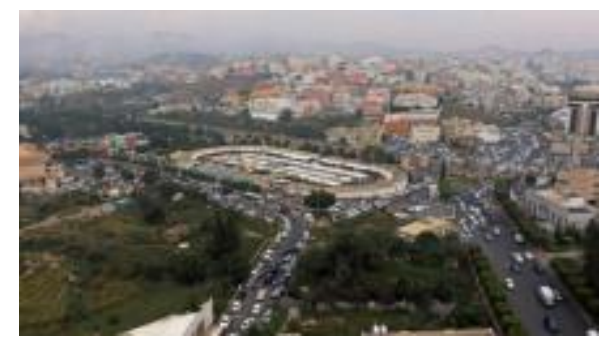

Fig. (6) Illustrates Abha streets, (feedyeti, 2018)

\subsection{Sources of Potable Water in Abha and Asir Province}

Saudi Arabia is a very arid country with little rainfall and no permanent freshwater sources such as rivers or lakes (watersaving - Switzerland, 2014). Three quarters of Saudi Arabia's freshwater comes from non-renewable groundwater. 
Contrariwise, Asir province has an average rainfall of $278 \mathrm{~mm}$, which means that it is enough for human use and irrigation.

Many projects of dam's construction took place in the territory of Asir. For example, dam rainfall in the city of Abha fig (7). Tens of dams has been constructed and planned more than this number in KSA vision 2030. All these projects give advantages to Abha city to be selected as eco-city.

Fig. (7) Dam rainfall, Abha, (Titi, 2016)

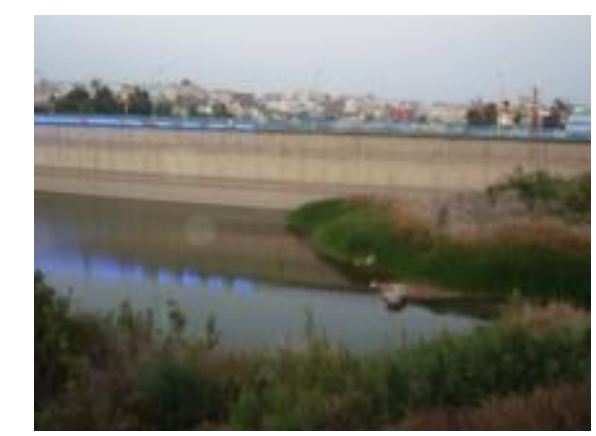

\subsection{Generating Renewable Energy in Saudi Arabia}

Saudi Arabia is seeking investment of up to $\$ 7$ billion of investment in the coming year to build about 4,000MW of renewable energy capacity, as part of its plan to supply $9,500 \mathrm{MW}$, or $10 \%$ of its power demand, from renewable sources by 2023 . (Scott, 2018)

Saudi, the world's largest oil producer, is looking to generate more energy from renewable sources, in part to reduce its greenhouse gas emissions as part of the Paris Accord on climate change, but also to allow it to sell oil abroad at full price rather than use it domestically where it is heavily subsidised. Developing a renewable energy industry is also part of its Vision 2030. In a sign of how rapidly the kingdom's renewable energy sector is developing, it will tender for 3,200MW of solar power and 800MW of wind, this year, compared to $700 \mathrm{MW}$ in 2017 . It will also look at other sources of power, including concentrated solar power (CSP) and waste-to-energy. (Scott, 2018)

\subsection{Urban Developments in Abha}

The urban development growth in Abha is running very fast, meanwhile urban development should be controlled by a sustainable planning and management vision that encourage integration between green space, sustainable transportation system, and mixed-use development. In addition, policymakers, developers, and contractors should support sustainable site planning and construction techniques that reduce pollution. They should ensure the balance between ecology and buildings (American society of landscape architects, 2018). In fig (8) we can see the difference between existing situations of urban development in Abha against Copenhagen which is the best eco-city in the world. There is no protection or development of green areas. The main interest is getting more plots for building to convoy the urban sprawl of the city. The concept doesn't change even for new urban development like El-Sarawat district fig (9). 

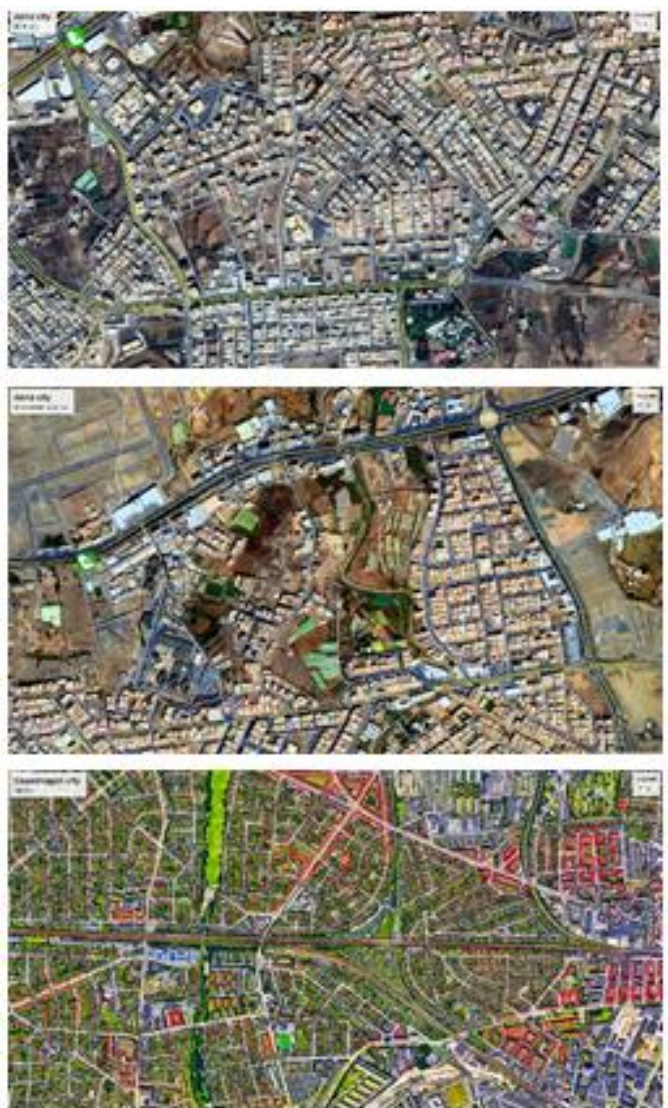

Fig. (8) Illustrates on the top \& middle Al-Mansak \& Al-Mwazafeen districts in Abha without green areas. Bottom Copenhagen, Denmark and the mixed-use developments (By researcher using Google Earth)

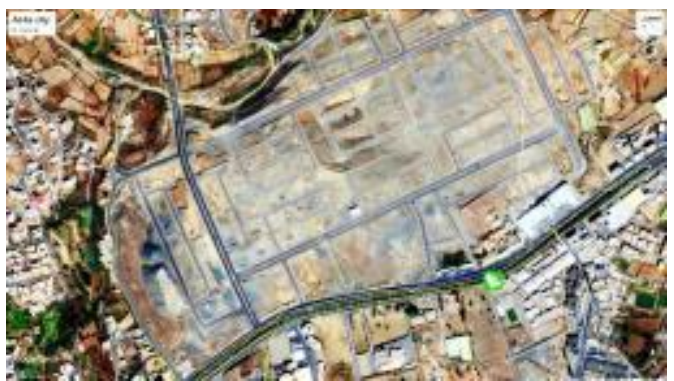

Fig. (9) New urban development El-Sarawat, Abha (By researcher using Google Earth)

\subsection{Asir Architectural Heritage and Ecology}

Villages in Asir has architectural heritage that respects the environment and human scale, use, culture, and taste. Every mountain village in Asir has a unique character. Asir province architectural heritage has different colour some are towering terraced houses clinging to the cliff faces, while others look cakes decorated with icing 
(SCTA, 2010) fig (10) \& (11). There is no sustainable development without respecting and searching for people heritage. It is obvious the beauty of buildings respecting mountain levels. Unfortunately, nowadays developers and contractors demolish the mountains and produce one level to can start construction. Asir arts like (El-Got ElAsiri) fig (11) which is accredited by Ionesco and produced by ladies in their homes in the past is not used anymore unless for exhibitions and forums.

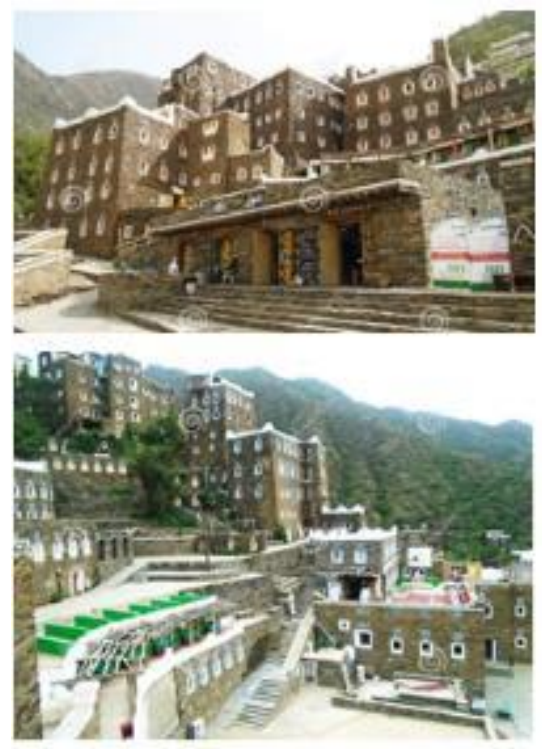

Fig. (10) Both top and bottom Rijal Almaa village architectural heritage, Asir (Reda, 2018)

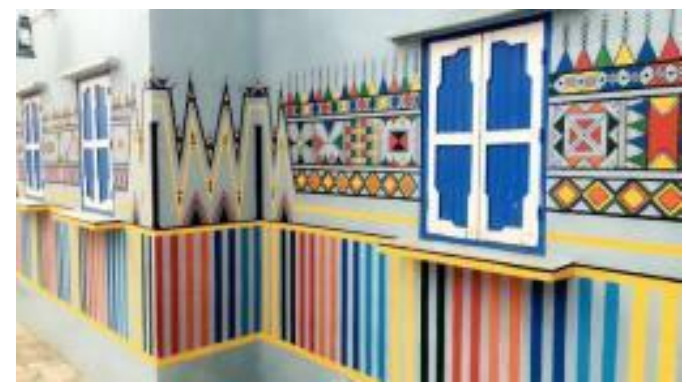

Fig. (11) Al-Got Al-Asiri, Asir (Al-Almaeiy, 2018)

\subsection{Building Materials in Abha's Heritage}

Using local materials for building construction in Asir heritage protects the indoor environmental quality for human use. These materials require little processing or transporting, the environmental and economic costs are low (Green home building, 2001). Local building materials are defined by individual characteristics such as VOC levels or recyclability. Bricks and tiles are absolutely free of pollutants and allergens. By specifying regional materials, however, a product's sustainability profile will extend to extraction, manufacturing, and transportation practices (Morton, 2013). 


\section{Methodology Steps for Abha to be an Eco-City}

\subsection{Developing Sustainable Transportation Plan for Abha \& Khamis Mushait Cities}

Abha city does not have any kind of public transportation unless very few number of taxi drivers and few buses for university female students. The main mean of transportation is private cars which cost the environment and the economy of the country a huge bill of pollution, carbon emissions, and loosing fossil fuel. In addition, Khamis Mushait acts as a market and serving city for Abha. It has low income houses and huge number of people living in Khamis Mushait are working in Abha. Also, it has lot of commercial shops and most of Asir trading done in Khamis Mushait. Then, we can't study the transportation plan of Abha ignoring connection and the transportation inside Khamis Mushait city.

The first step towards sustainable city is creating a full transportation plan based on using sustainable means of transportation. Traditional transportation have their bad impact on the environment, around $20 \%$ to $25 \%$ of world energy consumption and Carbon emissions (Jeon \& Amekudzi, 2005). In the following some types of suitable means of sustainable transportation could be used in Abha and Khamis Mushait cities.

\subsubsection{Installing Trolleybus}

Trolleybus is an electric bus that draws its electricity from overhead using spring-loaded trolley poles fig (12). Currently, around 300 trolleybus systems are in operation, in cities and towns in 43 countries. It has electric engine providing torque in the start-up with rubber tires not need underneath infrastructure. New models have gas engine for any failure (wikipedia, 2008).
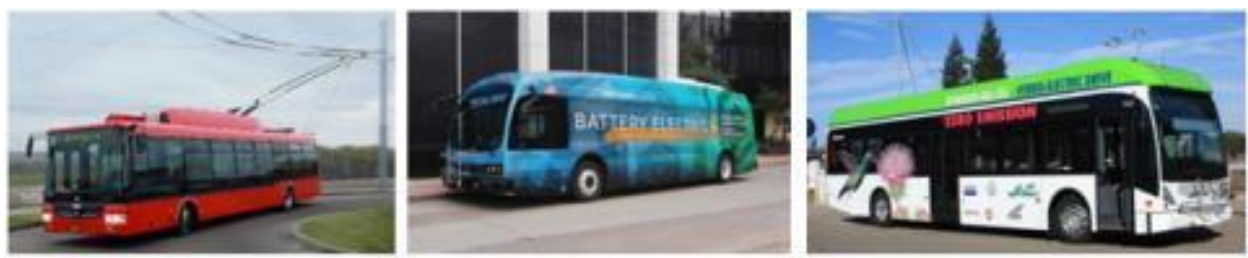

Fig. (12) On left trolleybus, (Skoda, 2018), In the Middle electric bus (Ptacek, 2018), on right, bybrid bus (FuelCellsWorks, 2018)

\subsubsection{Zero Emission Buses \& Fuel Cell Hybrid Bus Fleet}

The Zero Emission Urban Bus System, aims to be the main activity to extend the fully-electric solution to the core part of the urban bus. Hybrid buses produce only water vapor: no smog forming nitrogen oxides. fig (12) (Aboneama, 2015).

\subsubsection{Installing New Tram Lines between Abha and Khamis Mushait}

The distance between Abha and Khamis Mushait is around $25 \mathrm{~km}$. King Fahd road with its five lanes for each direction can include a tram line connecting both cities. This tram lane will cover a huge percentage from daily traffic between both cities fig (13). Rabat in Morocco and Athens development in 2004 for Olympic Games are 
samples. (Aboneama, 2015).
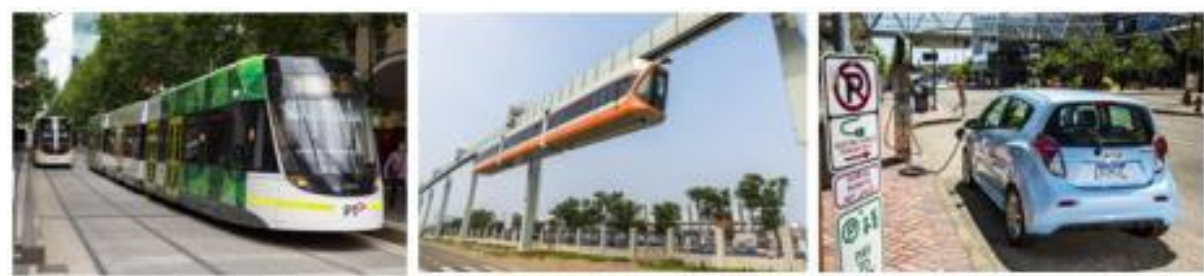

Fig. (13) On left tram, (govnews, 2015), In the Middle monorail (globalrailnews, 2018), on right, zero emission car "electric car" (Carter, 2014)

\subsubsection{Installing Monorail for Heavy Traffic Places}

The A monorail is a railway in which the track consists of a single rail, typically elevated. The interesting issue about monorail is its ability to be installed inside an old crowded city.

\subsubsection{Zero Emission Vehicles}

A green vehicle produces less harmful impacts to the environment than normal cars. Policy makers can encourage the people to buy these kind of cars in Saudi Arabia by eliminating any taxes or customs for this kind of cars, and provide stations for car charging or alternative fuel supply (wikipedia, 2009).

\subsection{Improving Pedestrian Lanes and Bicycles}

A bikeway is a lane, route, way or path which in some manner is specifically designed and / or designated for bicycle travel. Roads often have a designated footpath for pedestrian traffic, called the sidewalk. Regular walking is important both for human health and for the natural environment (Schmitt, 2013).

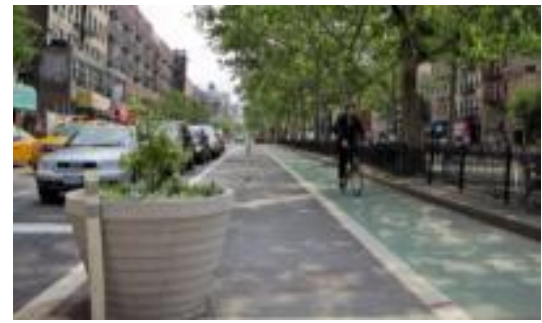

Fig. (14) Pedestrian lanes and bicycles (Schmitt, 2013)

\subsection{Generating Energy from Renewable Energy Sources}

As The energy consumption per capita reflects the level of living in the country and in most countries reflects the needs of energy for industrial needs. Unfortunately, as illustrated in the below map that Saudi Arabia is one of the highest country for energy consumption. Generating energy from renewable sources has become a mandatory. Using wind turbines, solar energy, hydro energy which is very suitable in Asir province, geo-thermal, and bio energy is not an option for energy production. 


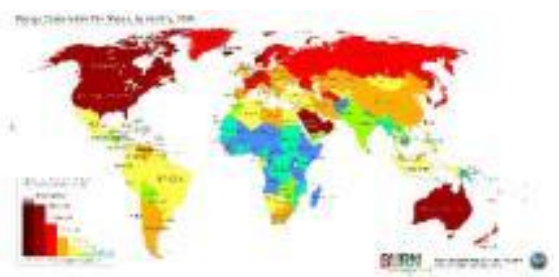

Fig. (15) Energy consumption per person by country (burn an energy journal, 2010)

\subsection{New Sustainable Agriculture Techniques}

Studying the new sustainable agriculture techniques and applying the suitable from them to intended ecology. It will save water resources and increase the agriculture production. In addition, sustainable techniques will prevent using harmful components such as bad chemical pesticides or fertilizers in people food.

\subsection{Apply Passive Design Criteria for Building Designs}

Unfortunately, all buildings inside Abha city are totally different with Asir architectural heritage. They are all boxes with grey or white colors without any sense of Asir heritage. Local building materials, orientation, construction techniques, aesthetics, and people culture don't have any impact on buildings. As illustrated in fig (16) the whole kingdom houses have the same view.

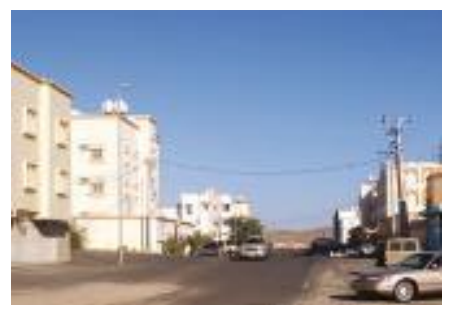

Fig. (16) Abha building's character (Manea, 2010)

Meanwhile, the architectural history of Asir province and the whole Middle East have abundant techniques for passive and environmental design such as courtyards, mashrabia, takhtaboosh, and orientation techniques fig (17). Passive design criteria is focusing on reduction of air-conditioning usage, and moves towards natural lighting and ventilation systems. Trying to achieve or get closer to zero-energy buildings.

Fig. (17) Passive design (Jain, 2013)

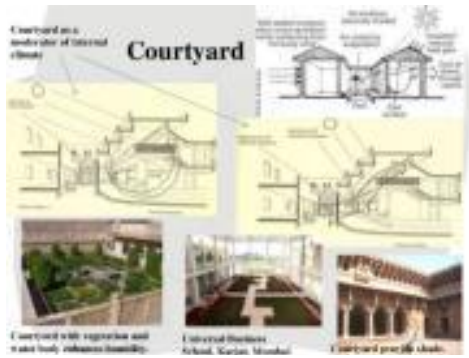




\subsection{Developing the Whole City Drainage Systems}

It is divided into two branches. First one is focusing on separating the main city infra-structure and buildings drainage systems for grey and black water. The existing systems in most of the cities now depend on mixing both types of waters. We can recycle and re-use grey water in flush tanks and irrigation to save potable water use. Secondly, to ensure separate or at least don't mix storm water harvesting with black water drainage system. Better to be totally separated or at least for economic reasons to combine it with grey water drainage system

\subsection{Xeriscaping - Garden and Landscape Design for Water Conservation}

To reduce the excessive use of water for maintaining landscapes, planners and planters are encouraged to adopt Xeriscape landscaping. This concept conserves water and protects the environment. Xeriscape landscapes need not be cactus and rock gardens. They can be cool, green landscapes full of beautiful plants maintained with water-efficient practices. the seven water-saving principles of xeriscape landscaping are; start with a plan, analyze and prepare the soil, be practical with turf areas, select appropriate plants, conserve moisture with mulches, use good maintenance practices, and use one of the following irrigation systems (sprinkler irrigation or drip irrigation) (Douglas F. Welsh, 2001).

\section{Results and Findings}

We can conclude from this research that we have an excellent opportunity to have Abha as a sustainable city in the Middle East which has an optimal weather conditions and rainfall average. Abha needs development in several ways such as transportation, urban planning, buildings architectural design, landscape, developing its drainage systems, enhance storm water harvesting, and searching for new resources of generating energy to achieve this goal.

\section{Discussion and Analysis}

Sustainable urban development, creating transportation plan with sustainable means, generating energy from renewable resources, applying passive design criteria on buildings, developing new water strategies and drainage systems based on sustainable and recycling principals require long term planning and should defined in 2030 vision of Saudi Arabia. Future planning will be divided into short, five-year stages to be able to confront all those serious challenges and solve all obstacles. Transforming Abha to be an eco-city is magnificent solution and guide way for many cities in the Middle East that have same challenges.

\section{Conclusion and Recommendations}

Transforming Abha to eco-city should be studied by governmental authorities in co-operation with practical experiments and getting the experience from other countries and cities that achieve this goal. Saudi Arabia institutions and authorities should work 
together in the highest level of amity. Solving problems in the shortest time is the only key words for this step. Implementing sustainable urban growth based on the potential of renewable energy production, developing sewage systems, applying passive design techniques on buildings, developing landscape strategies, sustainable agriculture techniques will create a new era for the Saudi Arabian economy and living standards.

\section{References}

Abdallah, A.-H. (2017, Jan 6). 2017. Retrieved from al-jazirah: http://www.aljazirah.com/2017/20170106/ew1.htm

Abir. (2015, Sep. 28). Abha photos. Retrieved from 3bir: https://v.3bir.net/345832/

Aboneama, W. (2015). Installing various means of sustainable transportation to achieve sustainable urban development and Cairo vision 2050. Future north Africa transportation summit (pp. 11-12). Cairo: IQPC.

Al-Almaeiy, I. (2018). abotalal40041. Retrieved from Twitter: https://twitter.com/abotalal40041

American society of landscape architects. (2018). sustainable urban development. Retrieved from www.asla.org: https://www.asla.org/sustainableurbandevelopment.aspx

Angus, H. (2014, Dec 18). What Makes a Bike Lane Great? Retrieved from momentummag.com: https://momentummag.com/what-makes-a-bike-lane-great/

burn an energy journal. (2010). MAP: How much energy is the world using? Retrieved from burnanenergyjournal.com: http://burnanenergyjournal.com/how-much-energy-are-we-using/

Carter, M. (2014, June 4). Eight US States Form Alliance to Put 3.3 Million Zero Emission Vehicles on the Road by 2025. Retrieved from inhabitat.com: https://inhabitat.com/eight-us-states-form-alliance-to-put3-3-million-zero-emission-vehicles-on-the-road-by-2025/

Douglas F. Welsh, W. C. (2001). Xeriscape Landscape Water Conservation. Texas: Texas agriculture extension service.

en.wikipedia.org. (2008). Sustainable city. Retrieved from Wikipedia: https://en.wikipedia.org/wiki/Sustainable_city

feedyeti. (2018). Abha. Retrieved from feedyeti.com: https://feedyeti.com/hashtag.php?q=abha

FuelCellsWorks. (2018, April 14). zero-emission-buses. Retrieved from fuelcellsworks.com: https:/ fuelcellsworks.com/news/zero-emission-buses-equipped-with-freudenberg-seals-setdurability-milestone

globalrailnews. (2018, June 2). CRRC tests suspended monorail called the 'Sky Train'. Retrieved from globalrailnews.com: $\quad$ https://www.globalrailnews.com/2017/07/27/crrc-tests-suspendedmonorail-vehicle/

govnews. (2015, Nov). Victoria taps Bombardier for new $\$ 274$ mil E-Class trams. Retrieved from govnews.com.au: http://www.govnews.com.au/victoria-taps-bombardier-for-new-274-mil-e-class-trams/

Green home building. (2001). Local materials. Retrieved from greenhomebuilding.com: http://www.greenhomebuilding.com/localmaterials.htm

Hiroaki Suzuki, W. B. (2010). Ecological cities as economic cities. (ISBN 978-0-8213-8046-8): Synopsis.

Hoiberg, D. H. (2010). Encyclopadia Britannica (Vol. 15th ed). A-ak Bayes.

Hoiberg, D. H. (n.d.). Abha. Retrieved June 4, 2018, from Wikipedia: https://en.wikipedia.org/wiki/Abha

Jain, A. (2013, Nov 29). passive techniques. Retrieved from slideshare.net: https://www.slideshare.net/anvitajain3/passive-techniques

Jeon, C. M., \& Amekudzi. (2005). Sustainable_transport. Retrieved from en.wikipedia.org: https://en.wikipedia.org/wiki/Sustainable_transport

Liu, H., Wennersten, R., Luo, P., Jiang, L., \& Dong, a. W. (2016). Conceptual Sustainability Framework for Eco-City Development in the City Core of Xuzhou. Journal of Urban Planning and Development, Volume 142, Issue 4. Retrieved from ascelibrary.org: https://ascelibrary.org/doi/10.1061/\%28ASCE\%29UP.1943-5444.0000319

Manea, M. (2010, Dec 28). Teenagers bother Al-Mansek district with drifting. Retrieved from alwatan.com.sa: http://www.alwatan.com.sa/Politics/News_Detail.aspx?ArticleID=34996 
Morton, J. (2013, Jan 25). Regional Materials: Benefits and Advantages. Retrieved from buildings.com: https://www.buildings.com/article-details/articleid/15165/title/regional-materials-benefits-andadvantages/viewall/true

Pantsios, A. (2014, Oct. 24). top-10-greenest-cities-in-the-world. Retrieved from ecowatch.com: https://www.ecowatch.com/top-10-greenest-cities-in-the-world-1881963132.html

Ptacek, K. (2018, Jan 10). zero-emission-all-electric-buses. Retrieved from dartdallas.dart.org: http:/ / dartdallas.dart.org/2018/01/10/dart-demos-new-proterra-zero-emission-all-electric-buses /

Reda, A. (2018). rijal-alma-heritage-village-located-assir-region. Retrieved from dreamstime.com: https://www.dreamstime.com/rijal-alma-heritage-village-located-assir-region-capital-almaaprovince-was-natural-corridor-linking-image107226437

Rigester, R. (2008). advantages-and-disadvantages. Retrieved from ecocitiescatq3rene: https://ecocitiescatq3rene.weebly.com/advantages-and-disadvantages.html

saudi-arabia/energy-consumption. (n.d.). Retrieved from World Data: https://www.worlddata.info/asia/saudiarabia/energy-consumption.php

Schmitt, A. (2013, July 31). The Rise of The North American Protected Bike Lane. Retrieved from momentummag.com: https://momentummag.com/the-rise-of-the-north-american-protectedbike-lane/

Scott, M. (2018, Jan 18). Saudi Arabia Plans To Source 10\% Of Its Power From Renewable Energy Within 5 Years. Retrieved from forbes.com: https://www.forbes.com/sites/mikescott/2018/01/18/saudi-arabiaplans-to-source-10-of-its-power-from-renewable-energy-within-5-years/\#3fb41fd $9485 \mathrm{f}$

SCTA. (2010). Asir-Mountain-Villages. Retrieved from arriyadh.com: http://www.arriyadh.com/Eng/Tourism/Left/KSAAttract/Asir/Asir-MountainVillages.doc_cvt.htm

Skoda. (2018). trolleybus-30-tr. Retrieved from skoda.cz: https://www.skoda.cz/en/references/trolleybus-30$\mathrm{tr} /$ ?from $=$ prod

Titi, A. (2016). Dam rainfall in the city of Abha. Retrieved from ar.wikipedia.org:

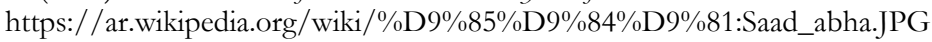

vacationidea. (2016). best-time-to-visit-copenhagen-denmark. Retrieved from vacationidea.com: https://vacationidea.com/tips/best-time-to-visit-copenhagen-denmark.html

watersaving - Switzerland. (2014, May 6). saudi-arabia. Retrieved from watersaving.com: https://www.watersaving.com/en/infos/saudi-arabia/

Weather spark. (n.d.). Average-Weather-in-Abha-Saudi-Arabia-Year-Round. Retrieved June 2, 2018, from Weatherspark: https://weatherspark.com/y/102305/Average-Weather-in-Abha-Saudi-ArabiaYear-Round

Wienerberger. (2004). clay-building-materials-advantages. Retrieved from wienerberger.com: https://claywienerberger.com/expertise/clay-building-materials-advantages

wikipedia. (2008). Trolleybus. Retrieved from en.wikipedia.org: https://en.wikipedia.org/wiki/Trolleybus

wikipedia. (2009). Zero-emissions_vehicle. Retrieved from en.wikipedia.org: https://en.wikipedia.org/wiki/Zeroemissions_vehicle

wikipedia. (2012, June 6). wikipedia. Retrieved from Oil_reserves_in_Saudi_Arabia: https://en.wikipedia.org/wiki/Oil_reserves_in_Saudi_Arabia

Wikipedia. (2016, April 25). Saudi_Vision_2030. Retrieved from Wikipedia: https://en.wikipedia.org/wiki/Saudi_Vision_2030

Willmott, D. (2014, September 22). building-the-worlds-first-carbon-neutral-city. Retrieved from smithsnoian.com: https://www.smithsonianmag.com/innovation/building-the-worlds-first-carbon-neutral-city$180952772 /$ 